\title{
Intensifying agricultural crops production by means of thermal reclamation
}

\author{
Oleg Pinchuk ${ }^{1, *}$, Serhii $\mathrm{Klimov}^{1}$, Ivan Romaniuk ${ }^{1}$, Florin Faur ${ }^{2}$, Maria Lazăr², and Izabela-Maria $\mathrm{Apostu}^{2}$ \\ ${ }^{1}$ National University of Water and Environmental Engineering, Department of Hydroinformatics, Rivne, Ukraine \\ ${ }^{2}$ University of Petrosani, Faculty of Mining, Department of Environmental Engineering and Geology, Petrosani, Romania
}

\begin{abstract}
The use of surface heating with heat exchangers significantly affects the temperature regime of the soil and the surface air layer. It is manifested in a change in the distribution of temperatures according to the soil horizon, in a considerable increase in the temperature of the soil and air, in a change of heat exchange between the soil and the surface layer of air. When using tunnel greenhouse, heating the soil with the coolant temperature of $25 \ldots 30{ }^{\circ} \mathrm{C}$ contributes to the creation of all necessary conditions in ground area equipped with a heat exchangers for shifting the vegetation period of ultra-early cultivation of agricultural crops, on average, by 1-2 months depending on the crop type. This allows for earlier sowing and planting of thermophilic crops and getting harvest earlier than usual, as well as increasing the amount of crop production and improving its quality. The thermal efficiency of soil heating with water-filled flexible sleeves was studied experimentally in a field model experiment performed in the climatic terms of the Ukrainian Polissya on sandy loam and chernozem soils. Strawberry of the "Festivalny" type was used as the main crop-indicator. The influence of soil heating with heat exchangers on the growth, development and yield of strawberries has been studied.
\end{abstract}

\section{Introduction}

The problem of getting early and permanent yields of agricultural crops, particularly vegetables and berries; flowers of saleable quality is one of the major socioeconomic issue in agriculture of many countries. Climate change and weather conditions, which are becoming unpredictable, exacerbate the urgency of the problem. In the generally accepted tendency of global warming, experts also pay attention to the possibility of local temperature decreases in some areas, prolonged cold periods in spring, considerable fluctuations of weather conditions [1-4].

Studying the influence of possible climatic and weather changes on the development and productivity of agricultural crops production and developing measures to prevent the negative climatic and weather phenomena are becoming relevant in agriculture not only for researchers but also for professional practitioners

The role of climate in improving soil fertility is wellknown, scientists have even introduced a concept "agricultural fertility of the climate" as the ability of the atmosphere and the underlying surface to provide a certain level of soil fertility and agricultural crops yield through climatic resources. It is thus emphasized that the soil properties, its natural and effective fertility are manifested only in the presence of certain amount of moisture in the soil and at a certain thermal regime [5-7].

Thermal resources play a significant role in yield formation. Each plant has its own strictly individual thermal-temporal structure of the development cycle from sowing to harvesting. The parameters of this cycle are strictly related to the corresponding level of temperatures in the soil and air. Therefore, purposeful control of plant ontogenesis can be possible by controlling the thermal regime of the microenvironment of its habitat. It is obvious that the thermal regime of the soil and the surface layer of air will be also decisive for the intensification of the processes of growth and early cultivation of crops.

The analysis of meteorological observations in the Ukrainian Polissya shows that the danger of low temperatures persists at night and in the early morning hours practically throughout the entire spring period. For instance, the frosts up to $-10^{\circ} \mathrm{C}$ took place daily until March, 25, the transition of minimum air temperatures to more than $-10^{\circ} \mathrm{C}$ took place on April, 10. During April, nighttime sub-zero temperatures of air persist. Even in April, the air temperature drops to $-1{ }^{\circ} \mathrm{C}[8,9]$.

These features of temperature conditions of the Ukrainian Polissya do not allow the active vegetation to begin in March-April, especially for thermophilics crops, and force to postpone the active soils use to May. The task of heat supply for crop production in the early spring periods is traditionally solved by creating greenhouse facilities and by heating the soil. Thus, high-temperature sources of thermal energy are used for heating the soil and air in cultivation facilities, which are obtained by burning high-value fuels, primarily natural gas.

Significant increase in the price of natural fuels and thermal energy puts on the agenda the tasks of finding, justifying and developing alternative ways to regulate the thermal regime of the soil and air, sources of alternative

\footnotetext{
* Corresponding author: o.l.pinchuk@nuwm.edu.ua
} 
energy with the purpose of getting early harvests of agricultural crops.

\section{Materials and methods}

One option for solving this problem can be creation of soil areas heated by special thermal reclamation facilities using thermal wastes from industry. Hot water (heatexchange water) from industrial and power-generating facilities with the temperature of $20-40{ }^{\circ} \mathrm{C}$ and geothermal water can be used as attractive free sources of thermal energy [6, 10-12]. Their attractiveness is that such temperatures are optimal for the development of most crops.

In the $80 \mathrm{~s}$ of the last century in many developed countries of the world, in the USA, France, Germany, the former Soviet Union, and in particular at our National University of Water and Environmental Engineering, long-term researches of the efficient use of the charged hot water from nuclear power plants and thermal power plants for heating the soil by the pipeline systems were conducted [13-23]. The pipeline systems showed sufficient efficiency in increasing the productivity of separate agricultural crops and enabling earlier harvesting. However, their thermal efficiency in relation to the surface layer of air was low $\left(0,5 \ldots 1,5^{\circ} \mathrm{C}\right)$, which did not allow them to find wide application as an effective method of heating reclamation, except for some engineering problems (cooling of water in soil, accumulation of heat in the soil, heating of sports grounds, etc.).

One of the promising and effective methods of thermal reclamation of adjacent areas, in our view, can be the surface heating of soil with warm water with the temperature parameters within $25 \ldots .35^{\circ} \mathrm{C}$.

The working scientific hypothesis is that the maximum thermal effects when using water with such temperatures should be expected with directing the water flows to the area of plants habitat. The transfer of thermal resource in the amount of $15 \ldots 20^{\circ} \mathrm{C}$ to the environment "soil - air" will theoretically allow shifting the transition through $10^{\circ} \mathrm{C}$ to the end of February - beginning of March (fig. 1).

Technologically, this technique can be implemented by directing the water flow in a thin layer on the soil surface, and can be technically executed with the application of special sleeves - heat-exchangers of various designs and geometry, made of thin, long lasting, flexible polymeric materials - films (fig. 2).

The thermal efficiency of soil heating with waterfilled flexible sleeves was studied experimentally in a field model experiment performed in the climatic terms of the Ukrainian Polissya on sandy loam and chernozem soils [24-25]. Strawberry of the "Festivalny" type was used as the main crop-indicator. The soil was heated with specially heated warm water, which circulated by gravityflow under a small initial pressure $(10 \ldots 20 \mathrm{~cm})($ fig. 2). The temperature of water in the sleeves was automatically maintained within $24 \ldots 26^{\circ} \mathrm{C}$ in March with a subsequent increase in April and May up to $27 \ldots 30^{\circ} \mathrm{C}$.

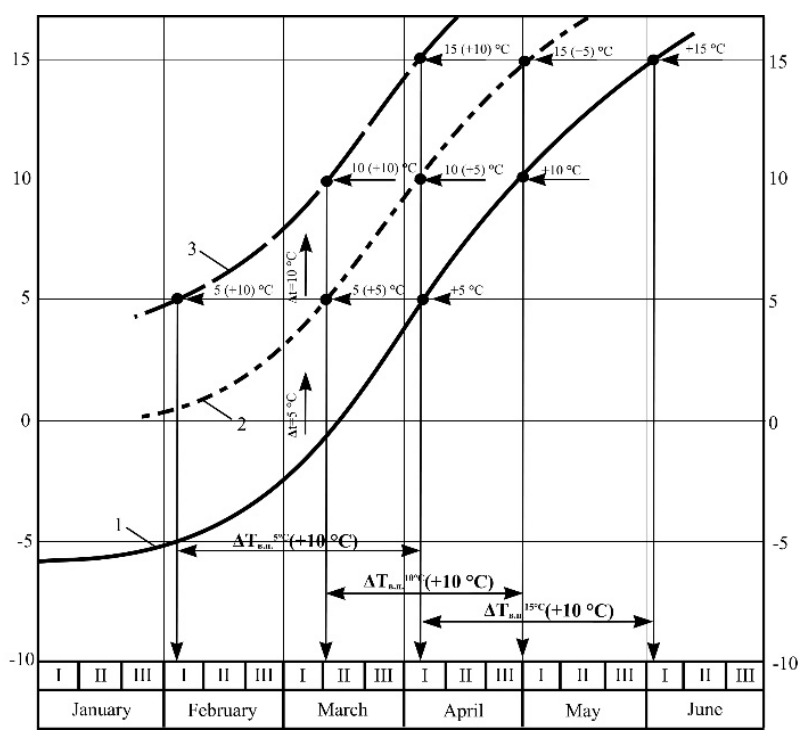

Fig. 1. Forecast of the efficiency of heat reclamation for the conditions of Ukrainian Polissya: 1 - average ten-day long-term temperatures of the surface air layer (Rivne); 2 - increased air temperatures by $5^{\circ} \mathrm{C} ; 3$-increased air temperatures by $10^{\circ} \mathrm{C}$.
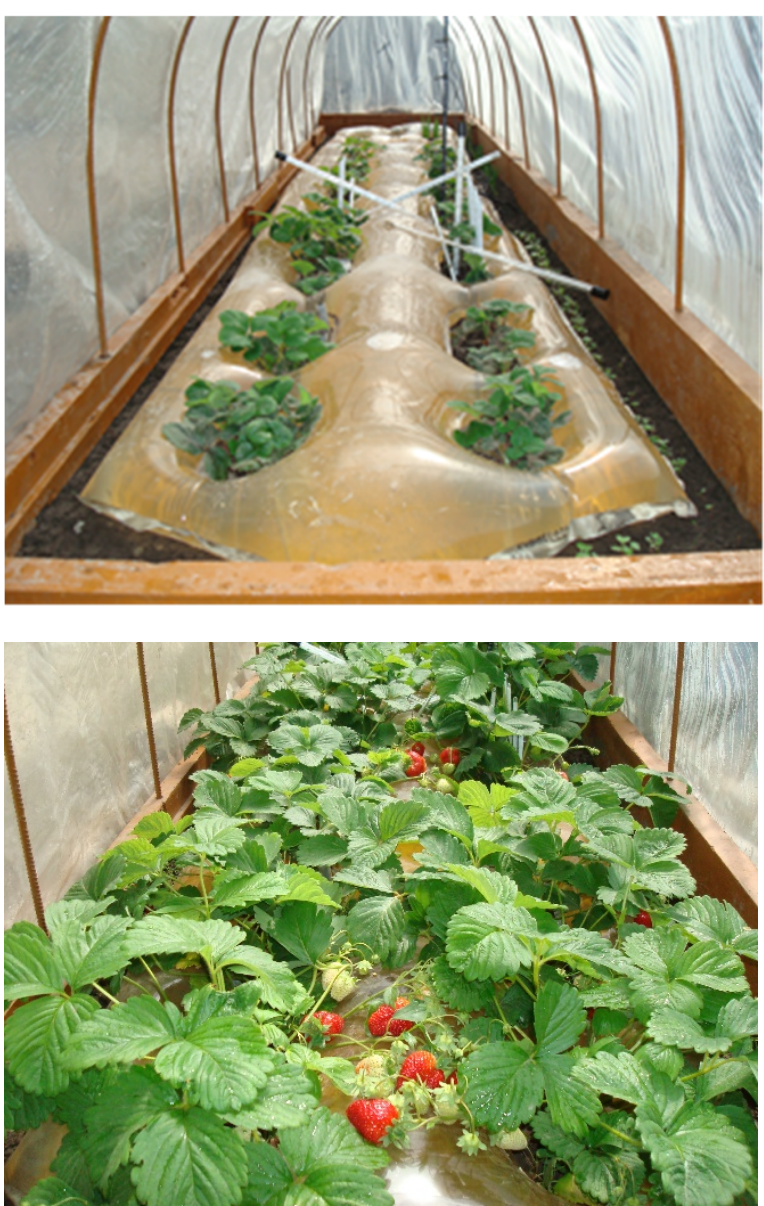

Fig. 2. A general view of heat-exchanger with plants.

The temperature of the soil, air and water circulating in heat-exchangers was measured by precise laboratory meteorological mercury thermometers, by Savinov thermometers to the depth of $20 \mathrm{~cm}$, by buried thermometers in depth, electric thermometers, and aspiration psychrometers. In the experiment, part of the heated adjacent areas was additionally protected by tunnel 
type film greenhouse (Fig. 2). For this purpose, polyethylene film with the thickness of $150 \mathrm{mkm}$ was used. The water was heated by an automatic water heating device, the heated water supply was regulated by dampers and valves.

\section{Results and discussion}

The initial stage of soil heating by heat-exchangers was studied by us since March, 12, 2009 during two weeks. All parameters were measured twice a day at 7:00am and 7:00pm. The basic results of measuring the temperature of soil, water and air, are shown in Figure 3. An open heated ground in natural conditions was taken as a control option.

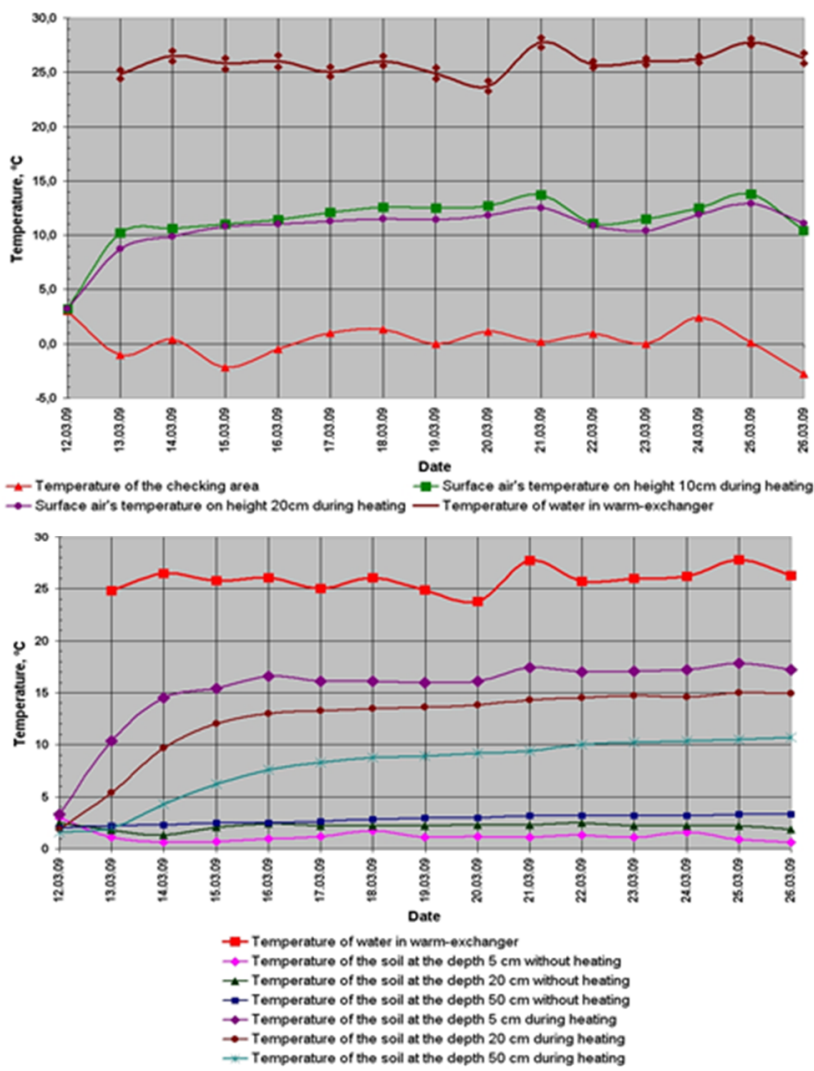

Fig. 3. The research results of surface air (A) and soil (B) temperature in March 2009.

The research results show that surface heating is an effective technical method of thermal reclamation of the plants habitat, which makes it possible to quickly and reliably increase the temperature of the soil and the surface air when using a film cover. On the third day of operation of heat exchangers, the temperature in the upper $20 \mathrm{~cm}$ soil layer rose to $10 \ldots 14^{\circ} \mathrm{C}$. At the same time, due to the heat flow from the surface of heat exchangers upwards, the surface air layer warmed up to $8 \ldots 11^{\circ} \mathrm{C}$.

On the fourth-fifth day of the heating system operation, favorable temperature conditions were created at the level of $14 \ldots 16^{\circ} \mathrm{C}$ in the upper $20 \mathrm{~cm}$ layer of soil and about $10 \ldots 12{ }^{\circ} \mathrm{C}$ in the surface layer of air, which were constantly preserved even on cloudy and frosty days. Therefore, heating with heat exchangers, which is very important, is guaranteed to maintain the positive air temperature at night and protect plants from frost.

The soils temperatures obtained as a result of constant heating $\left(14 \ldots 16^{\circ} \mathrm{C}\right)$ promote the germination and development of most vegetable and berry crops, even thermophilic ones. In this case, under natural conditions, soil and air temperature remain very low, varying from - 2 ${ }^{\circ} \mathrm{C}$ to $+3{ }^{\circ} \mathrm{C}$. The whole period of observations of the soil in natural conditions remained unprepared for agricultural use due to low temperatures. It should be noted that at this time there was precipitation in the form of snow and cold rain. The snow that fell remained on the surface of the control area, while on the surface of the film cover it melted and turned into water.

Heat-exchangers constantly consumed thermal energy, and consequently water cooled down. As a result of measurements and calculations of thermal energy, its consumption amounted to $700-800 \mathrm{Wt} / \mathrm{h}$ or $200-220 \mathrm{Wt} / \mathrm{h}$ per one square meter of soil which was heated, and water in the sleeves cooled down by $0,6 \ldots 0,9^{\circ} \mathrm{C}$.

Observations of the soil temperature have shown that the effect of heating extends to a considerable depth. Thus, according to the results of measurements in 2009, the soil temperature at a depth of $1 \mathrm{~m}$ under heat exchangers after two weeks of their operation rose to 6.4 ${ }^{\circ} \mathrm{C}$, while in the control area it amounted to $4{ }^{\circ} \mathrm{C}$ (table 1).

Obviously, soil heating can be carried out at the depth of $2 \mathrm{~m}$ and more. In this case, an array of heated soil is created under the heat exchanger, accumulating significant reserves of thermal energy. This reserve of thermal energy guarantees the protection of the upper root layer of the soil from penetration of negative temperatures from the lower soil layers.

Table 1. Temperature of the soil in the area that is heated and in the control area in different points of the soil profile, ${ }^{\circ} \mathrm{C}$ (of March 26, 2009 at 7:00 am).

\begin{tabular}{|c|c|c|}
\hline Depth, cm & Control area & Heated Soil \\
\hline 0.0 & -0.3 & $15.4-22.8^{*}$ \\
\hline 5.0 & 0.6 & 17.5 \\
\hline 10.0 & 0.8 & 17.2 \\
\hline 15.0 & 1.6 & 16.8 \\
\hline 20.0 & 1.9 & 15.8 \\
\hline 30.0 & 2.7 & 13.5 \\
\hline 40.0 & 3.0 & 11.8 \\
\hline 50.0 & 3.3 & 10.7 \\
\hline 60.0 & 3.4 & 9.7 \\
\hline 80.0 & 3.6 & 7.5 \\
\hline 100.0 & 4.0 & 6.4 \\
\hline
\end{tabular}

*Note: lower value corresponds to the soil temperature at input of the heat exchanger, higher one - to the temperature of the soil above the heat exchanger.

Great importance in assessing the temperature of the heated soil is attached to the peculiarities of its formation during the vegetation period (March-May), as well as during the day. According to the results of our research in 2004-2013, conducted on sandy loam soils of the Ukrainian Polissya, the influence of the surface heating is more noticeable in cold periods (March, April). The constant inflow of heat from the heating system prevents penetration of negative temperatures into the soil and 
maintains the temperature background in the habitat of plants at the levels close to optimal $[6,11,26]$.

The temperature regime of the soil in the daily cycle, due to the frequency of receiving solar heat, is characterized by a slow change of temperature values from maximum to minimum, which changes with time and depth.

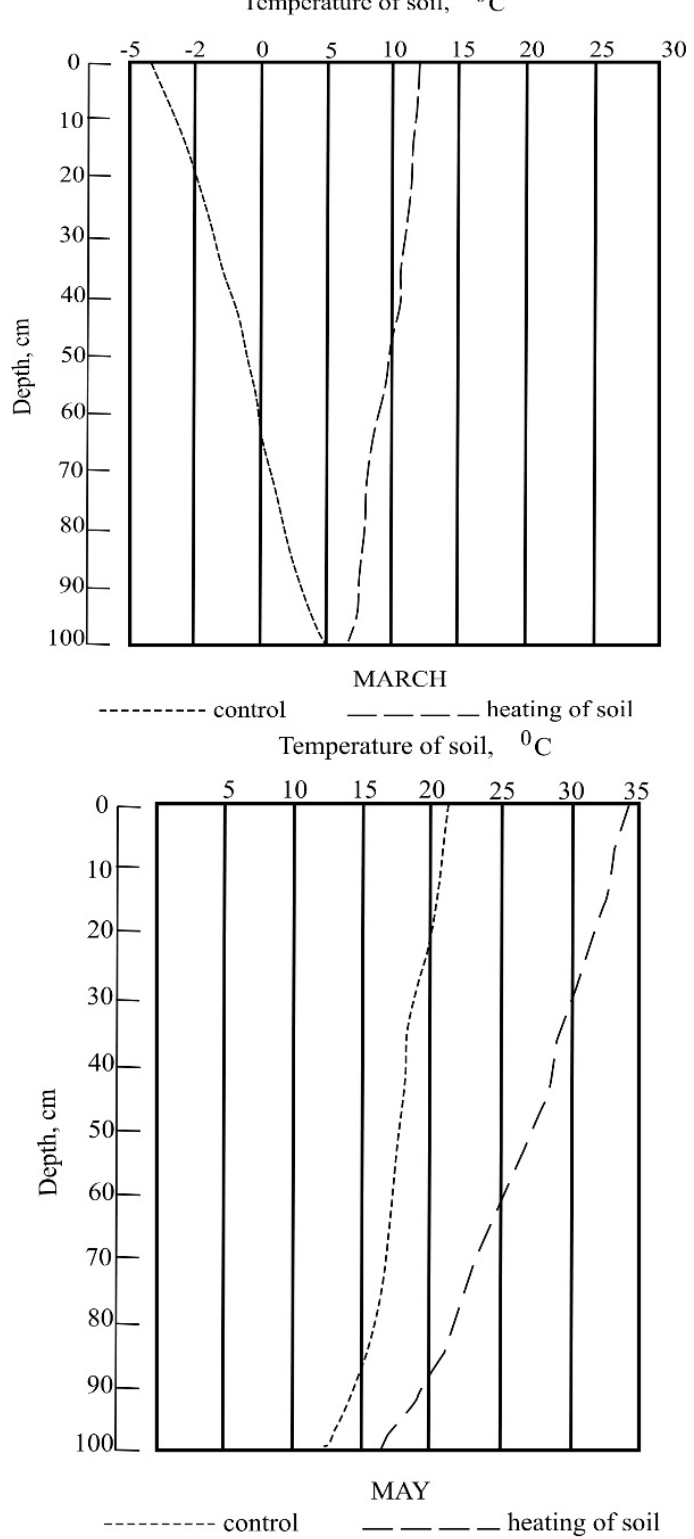

Fig. 4. Profile changes of average monthly soil temperatures in 2009.

In the course of our research it is found out that the general nature of temperature changes during the day, both in the heating section and in the control one it remained the same. For example, the maximum temperatures of soil at the depth of $5 \mathrm{~cm}$ for the heated area are reached at $4: 00 \mathrm{pm} . .6: 00 \mathrm{pm}$ and are within $27 \ldots 29{ }^{\circ} \mathrm{C}$, while in the control area - at 5:00-6:00pm reaching the temperature $18 \ldots 19^{\circ} \mathrm{C}$. The minimum soil temperatures are observed in the heated area at 7:008:00am and are $19 \ldots 20^{\circ} \mathrm{C}$, and in the control area they reach $12 \ldots 13^{\circ} \mathrm{C}$ at the same time. The process of heat exchange in the "soil-air" system and the direction of heat flows depend on the thermal gradient conditions in the soil. The heated soil is characterized by the presence of maximum temperatures in the area where heat exchangers are located (surface soil), therefore, the dynamics of merging gradients and their type of movement must be investigated for a considerable soil layer (fig. 4) [6, 2728].

In March, 2009, soil temperature at the depth from 0 to $20 \mathrm{~cm}$ in the control area was below zero, while in the heated area it reached $11 \ldots 13^{\circ} \mathrm{C}$. In the layer from 20 to $80 \mathrm{~cm}$, the temperature of control soil changed from $0,5^{\circ} \mathrm{C}$ to $3.5^{\circ} \mathrm{C}$, and in the heated area it ranged from $8^{\circ} \mathrm{C}$ to $11^{\circ} \mathrm{C}$.

A completely different picture is observed in May. For example, in the soil layer ranging from 0 to $20 \mathrm{~cm}$ in the control area, the temperature is $20 \ldots 21{ }^{\circ} \mathrm{C}$, and in the heating area $-31 \ldots 34^{\circ} \mathrm{C}$. In the layer from 20 to $80 \mathrm{~cm}$ in the control area, the soil temperature is $16 \ldots 20^{\circ} \mathrm{C}$, and in the heating area $-26 \ldots 32^{\circ} \mathrm{C}$.

Although heating with heat exchangers using warm water cannot create optimal temperatures in the upper soil layer immediately after starting the system, but in late March and early April contributes to its increase by $10^{\circ} \mathrm{C}$ and more, and in mid-April - by $15^{\circ} \mathrm{C}$ and more. At the control site, the temperature reaches $10^{\circ} \mathrm{C}$ in late April, and $15^{\circ} \mathrm{C}$ in mid-May.

The increase in periods of soil heating and increase in absolute temperatures during these periods result in the increase in the sum of soil temperatures during vegetation period (table 2).

Table 2. The sum of soil temperatures more than 5, 10, 15 and $20{ }^{\circ} \mathrm{C}$ at the depth of $20 \mathrm{~cm},{ }^{\circ} \mathrm{C}$

\begin{tabular}{|c|c|c|}
\hline Temperature, ${ }^{\circ} \mathbf{C}$ & Heating with heat exchangers & Control \\
\hline 5 & 8125 & 6348 \\
\hline 10 & 7240 & 5886 \\
\hline 15 & 6430 & 4522 \\
\hline 20 & 4055 & 1925 \\
\hline
\end{tabular}

The obtained results demonstrate that from the point of view of positive temperatures accumulation, the option of soil heating with heat exchangers with the use of greenhouses provides very effective heat reclamation method.

The difference in sums of soil temperatures at the depth of $20 \mathrm{~cm}$ as compared to control area are more than $2000^{\circ} \mathrm{C}$

As our research has shown for the heated soil, the relationship between its temperature $(\mathrm{Y})$ at the depths of $5,10,20 \mathrm{~cm}$, air temperature (X) and water temperature in heat exchanger $(Z)$, can be described by the following empiric equations (for values of $Z>20^{\circ} \mathrm{C}$ ):

$$
\begin{gathered}
Y_{0.05}=X+0.14 \times Z-0.48 ; R_{x y z}=0.95 \\
Y_{0.1}=X+0.15 \cdot Z-1.76 ; R_{x y z}=0.95 \\
Y_{0.2}=X+0.12 \cdot Z-2.4 ; R_{x y z}=0.95
\end{gathered}
$$

When using tunnel type greenhouses, soil heating with heat exchangers with water temperature of $25 \ldots .30{ }^{\circ} \mathrm{C}$ helps create all the necessary temperature conditions for shifting the vegetation period and early growth of agricultural crops, on average, from one to two months depending on the type of crop. 
The moment that determines the beginning and suspension of active vegetation of plants is the date of transition of air and soil temperature through $10^{\circ} \mathrm{C}$. With the onset of the dates of temperature transition through $10^{\circ} \mathrm{C}$, the same patterns appear along with the beginning of active temperatures period. In the area of heating by heat exchangers, the date of temperature transition through $10^{\circ} \mathrm{C}$ in the soil at the depth of $20 \mathrm{~cm}$ in 2009 fell on April 1, and in the control area - on April 22, that is 21 days earlier.

It is known that the criterion for assessing the effectiveness of any measures, including heat reclamation is the yield of crops. As a result of application of surface heating in a root-containing layer, there is a change of a whole complex of processes which, in the end, influences the growth, development and formation of crops.

We studied the effect of surface heating on the growth and development of the "Festivalny" strawberry type. The results of observations during March-May 2009 showed that the first leaf on the strawberry appeared on March 19 and at the same time it increased the appearance of the second leaf, and the third one appeared on March 23. Strawberries beginning of stolon (runner) formation in the area of soil heating on April 3 (code 41 according to the BBCH-scale of strawberry) [29], and on April 6, 5 flowers appeared and mass flowering began on April 9 and lasted throughout the second decade of April. Mass bud forming of strawberries was observed on April 21, and the first crop of ripe berries was harvested on April 25.

The dynamics of the strawberry harvest during the study period is presented in Table 3 .

Table 3. Dynamics of strawberry crop yield.

\begin{tabular}{|c|c|c|c|c|}
\hline \multirow{2}{*}{ Date } & \multirow{2}{*}{$\begin{array}{c}\text { The mass } \\
\text { of berries, }\end{array}$} & \multirow{2}{*}{$\begin{array}{c}\text { The average } \\
\text { weight of } \mathbf{1} \\
\text { berry, } \mathbf{g}\end{array}$} & $\mathbf{g} / \mathbf{~ m}^{\mathbf{2}}$ & $\begin{array}{c}\text { crop yield } \\
\text { g meter of } \\
\text { heat } \\
\text { exchanger }\end{array}$ \\
\hline 25.04 .2009 & 145,41 & 13,10 & 22,37 & 5,59 \\
\hline 01.05 .2009 & 475,45 & 14,28 & 73,15 & 18,29 \\
\hline 06.05 .2009 & 4754,5 & 16,06 & 731,46 & 182,87 \\
\hline 08.05 .2009 & 3670,77 & 13,97 & 564,73 & 141,18 \\
\hline 10.05 .2009 & 5306,17 & 13,04 & 816,33 & 204,08 \\
\hline 13.05 .2009 & 6716,24 & 13,86 & 1033,27 & 258,32 \\
\hline 15.05 .2009 & 3571,61 & 12,38 & 549,48 & 137,37 \\
\hline 19.05 .2009 & 2096,42 & 11,80 & 322,53 & 80,63 \\
\hline 21.05 .2009 & 1001,22 & 11,28 & 154,03 & 38,51 \\
\hline 25.05 .2009 & 645,65 & 11,63 & 99,33 & 24,83 \\
\hline Sum & $\mathbf{2 8 3 8 3}$ & $\mathbf{1 3 , 1 4}$ & $\mathbf{4 3 6 6 , 6 8}$ & $\mathbf{1 0 9 1 , 6 7}$ \\
\hline
\end{tabular}

\section{Conclusion}

Field research has shown that heating the soil with heat exchangers circulating hot water with the temperature of $25 \ldots 30^{\circ} \mathrm{C}$ increases the temperature of the arable layer by $12 \ldots 16^{\circ} \mathrm{C}$ in the soil, and by $7 \ldots 12^{\circ} \mathrm{C}-$ in the air, which provides sufficient conditions for plant growth and development in early spring.

It is proved that heating with heat exchangers allows the period of active soil use to start earlier in the spring by 40-60 days for sheltered soil, and also increases the amount of positive temperatures in the arable soil layer during the spring period by $1500 \ldots 2000^{\circ} \mathrm{C}$. Close linear relationships are established between the temperatures of soil, air and water in the sleeves.

It is established that the joint action of surface heating and solar radiation during the day leads to a rapid increase in air temperature and the need for ventilation of tunnel greenhouses. Intense ventilation leads to the loss of moisture that evaporates from the plants and drying of the upper 10-cm layer of soil, which causes the need to replenish moisture in the soil during the increase in strawberry yield. It is recommended to carry out two or three waterings in late April and early May at the rate of $150-200 \mathrm{~m}^{3} /$ ha.

The influence of soil heating with heat exchangers on the growth, development and yield of strawberries has been studied. Under the conditions of soil heating, ripening of strawberry berries occurs to about 40 days earlier than in the control area without heating, the total yield increases due to heating by $50 \%$ or more when compared to the control area.

Assessment of the introduction of surface heating technology for soil on the area of 1 hectare as an innovative project based on the methodology for assessing net discounted income gives a net discounted income of 32 thousand dollars when growing strawberries. The payback period for capital investments does not exceed 3 years.

At the same time, a number of scientific problems need further research, in particular the issues of rational designs of surface heating systems, heat exchangers, methods of soil protection and structures of greenhouses (translucent shelters), water supply and collection regimes, methods of soil water regulation [30], automation, control and management, operation of heating systems and ventilation systems of greenhouses, technologies of cultivation of agricultural crops, development of methods of thermotechnical and hydraulic calculation, methods of technical operation, etc.

\section{References}

1. A. Iglesias, L. Garrote, Adaptation strategies for agricultural water management under climate change in Europe, Agri. Wat. Man., 155, 113-124 (2015). doi:10.1016/j.agwat.2015.03.014

2. S.G. Boychenko, V.M. Voloshchuk, I.A. Doroshenko, Ukrainian Geographical Journal, 2, 5968 (2000)

3. A. Rokochynskiy, P. Volk, N. Frolenkova, N. Prykhodko, I. Gerasimov, O. Pinchuk, Sc. Rev. Eng. and Env. Sci., 28 (1), 3-13 (2019). doi:10.22630/PNIKS.2019.28.1.1

4. S. Boichenko, Dissertation, Odessa State Ecological University, 2007

5. A. Rokochynskiy, P. Volk, O. Pinchuk, V. Turcheniuk, N. Frolenkova, I. Gerasimov, J. of Wat. and Land Dev., 40, 149-153 (2019). doi:10.2478/jwld-2019-0016

6. O. Pinchuk, Journal «Prirodoobustrojstvo» (Environmental Engineering), 1, 6-11 (2015) 
7. A. Kucher, Agri. and Res. Econ., 1 (3), 119-138 (2017)

8. P. Kovalenko, A. Rokochynskiy, J. Jeznach, R. Koptyuk, P. Volk, N. Prykhodko, R. Tykhenko, J. of Wat. and Land Dev., 41, 77-82 (2019). doi: 10.2478/jwld-2019-0030

9. A. Skrypnyk, O. Zhemoyda, N. Klymenko, L. Galaieva, T. Koval, J. Ecol. Eng., 22 (3), 275-288 (2021)

10. I.V. Romanyuk, Dissertation, National University of Water and Environmental Engineering, 2007

11. O.L. Pinchuk, Dissertation, National University of Water and Environmental Engineering, 2012.

12. V. Hud, O. Pinchuk, P. Martyniuk, I. Gerasimov, P. Volk, Sc. Rev. Eng. and Env. Sci., 28 (4), 569-583 (2019). doi: 10.22630/PNIKS.2019.28.4.52

13. N.D. Aliev, Z. E. Ramasanova, Pow. Eng., 1, 56-60 (2003)

14. J. E. Alpert, Enwiron. Qualit., 5 (4), 400-405 (1976)

15. D. Cook, J. Norman, J. of Env. Qualif., 11 (1), 46-56 (1982)

16. H. Lucow, G. Reinken, Waste heat manag. and util., 3, 2395-2408 (1979)

17. L.M. Dwyer, H. N. Haynoe, J. L. B. Culley, Canad. J. Plant Scien, 6 (3), 619-628 (1990)

18. M. A. Hares, M. D. Novak, Soil Sc. Soc. Am. J., 56, 22-29 (1992)

19. L. Kren, Machine design, September, 100-106 (2004)

20. K. Rykbost, L. Boersma, Agronomy journal, 68, 9499 (1976)

21. G. Reinken, Wasser und Boden, 10, 260-264 (1978)

22. K. Rykbost, L. Boersma, Agronomy journal, 68, 9499 (1976)

23. G. Vogel, Dt. Agrotechnik, 13, 130-135 (1963)

24. D. Kurtener, A. Chudnovsky, Agrometeorologicheskie osnovy teplovoi melioratsii [The Agrometeorological Foundation of Thermal Melioration of Soil], (Hydrometeoizdat, Leningrad, 1979), $231 \mathrm{p}$.

25. D. Kurtener, A. Chudnovsky, Raschet i regulirovanie teplovogo rezhima $v$ otkrytom $i$ zashchishchennom grunte [Calculation and Control of the Thermal Regime in Open and Covered Soil], (Hydrometeoizdat Leningrad, 1969), 300 p.

26. V.P. Vostrikov, I.V. Romaniuk, O. L. Pinchuk, Bulletin NUWMNRU, 4 (40), 224-231 (2007)

27. V.P Vostrikov, V.S. Melnyk, O.L. Pinchuk, V. Hnatiuk, Bulletin NUWMNRU, 2 (54), 40-49 (2011)

28. A. Vlasyuk, V. Zhukovskyy, N. Zhukovska, O. Pinchuk, H. Rajab, WSEAS Trans. on Appl. and Theor. Mech., 15, 52-59 (2020). doi:10.37394/232011.2020.15.8

29. U. Meier (ed.) Growth stages of mono- and dicotyledonous plants (Julius Kühn-Institut, Quedlinburg, 2018)
30. S. Klimov, O. Pinchuk, S. Kunytskiy, A. Klimova, Journal of Water and Land Development 43, 90 (2019). doi:10.2478/jwld-2019-0066 